\title{
PEMBERDAYAAN PETANI KOPI MELALUI PENGUATAN KELEMBAGAAN DI DESA KAONGKE-ONGKEA KECAMATAN PASARWAJO KABUPATEN BUTON
}

\author{
Safrin Edy \\ Program Studi Agribisnis, Fakultas Pertanian \\ Universitas Muhammadiyah Buton \\ Jln. Betoambari, No. 36 Baubau \\ e-mail: safrinediumb@gmail.com
}

\begin{abstract}
The objectives of this study are: (1) to describe the form of empowerment of farmer communities through institutional strengthening of coffee farmers (2) to describe the model of farmer empowerment through institutional strengthening and (3) identify the obstacles encountered in empowering coffee farmers through institutional strengthening. The study was conducted in Kaongke Ongkea Village, Pasarwajo Subdistrict, Buton Regency in February April 2017. The study was conducted using qualitative methods. The object of research is coffee farmers involved in coffee processing groups. Data collected through in-depth interviews with informants. The results showed that the form of empowerment of coffee farmers through strengthening institutional farmers, namely: a) increasing the capacity of Human Resources and strengthening farming capital, b) the model of empowering farmer communities through strengthening farmer institutions, namely: creating a social situation or climate, strengthening the potential or power owned by farmers and protect from all their weaknesses, c) obstacles encountered in empowering farmers through institutional strengthening, among others: internal constraints namely: limited human resources, especially farmers and limited budgets at the farm level in developing farming. Afterwhile is an external obstacle, which is not yet established a good partnership between farmers.
\end{abstract}

Keywords: Empowerment, strengthening, institutions, food barns, farmers

\begin{abstract}
Abstrak
Tujuan penelitian ini adalah: (1) mendeskripsikan bentuk pemberdayaan masyarakat tani melalui penguatan kelembagaan petani kopi (2) mendeskripsikan model pemberdayaan petani melalui penguatan kelembagaan dan (3) mengetahui kendala-kendala yang dihadapi dalam pemberdayaan petani kopi melalui penguatan kelembagaan. Penelitian dilaksanakan di desa Kaongke Ongkea Kecamatan Pasarwajo Kabupaten Buton pada bulan Februari April 2017. Penelitian dilakukan dengan metode kualitatif. Obyek penelitian adalah petani kopi yang terlibat dalam kelompok pengolahan kopi. Data dikumpulkan melalui wawancara secara mendalam kepada informan. Hasil penelitian menunjukkan bahwa bentuk pemberdayaan petani kopi melalui penguatan kelembagaan petani yaitu: a) peningkatan kapasitas Sumber Daya Manusia dan penguatan modal usahatani, b) model pemberdayaan masyarakat tani melalui penguatan kelembagaan petani, yaitu: menciptakan situasi atau iklim sosial, memperkuat potensi atau daya yang dimiliki petani dan melindungi dari segala kelemahannya, c) kendala-kendala yang dihadapi dalam pemberdayaan petani melalui penguatan kelembagaan antara lain: kendala internal yaitu: terbatasnya sumberdaya manusia khususnya petani dan terbatasnya anggaran di tingkat petani dalam mengembangkan
\end{abstract}


usahatani. Dan kendala eksternal yaitu belum terjalinnya kemitraan yang baik antara petani.

Kata kunci: Pemberdayaan, penguatan, kelembagaan, lumbung, pangan, petani

\section{Latar Belakang}

\section{PENDAHULUAN}

Kabupaten Buton saat ini memiliki 12 jenis tanaman perkebunan yang dikembangkan dan merupakan komoditas unggulan daerah, yaitu ini yaitu aren atau enau, asam jawa, cengkeh, jambu mete, kakao, kapuk, kelapa dalam, kelapa hybrida, kemiri, kopi, lada dan pala. Komoditas kopi menjadi salah satu prioritas yang diupayakan pemerintah daerah melalui peran aktif penyuluh pertanian. Faktor lain yang sangat mempengaruhi adalah mulai meningkatnya permintaan kopi dipasar domestik maupun global. Sehingga hal ini dapat memberikan stimulus bagi petani dalam mengembangkan usahatani.

Pengembangan usahatani merupakan usaha peningkatan produksi atau hasil pertanian dalam berbagai macam produk primer yang bernilai ekonomi, sehingga dapat memberikan nilai tambah (added value) yang dinikmati pelakunya. Dengan adanya potensi tersebut perlu dikembangkan sebagai suatu sentra agroindustri. Sebagai suatu pendekatan pembangunan dari dalam (endogenous development) yang memanfaatkan sebesar-besarnya potensi wilayah sebagai modal dasar, dengan tetap menjaga kelestarian lingkungan dan dapat mendorong berkembangnya industri setengah jadi atau semi-secondary dan jadi (Pasaribu (2011).

Selain itu untuk mendukung pengembangan usahatani pengolahan seperti misalnya pengolahan kopi harus ada kesamaan persepsi petani terhadap agroindustri kopi yang baik atau posif akan berdampak terhadap perilaku petani dalam sistem pengohan kopi yang makin baik sehingga dapat meningkatkan pendapatan dan kesejahteraan petani (Edy S, 2016).

Daerah penghasil kopi yang perlu dikembangkan antara lain adalah di Desa Kaongkeongkea Kecamatan Pasarwajo yang merupakan salah satu daerah pengahasil kopi terbesar dan memiliki aroma dan citarasa yang khas. Petani telah melakukan proses pengolahannya sejak lama dan merupakan sumber pendapatan keluarga. Seiring perkembangan teknologi dan informasi, proses pengolahan kopi yang dilakukan telah mengalami kemajuan dengan melakukan inovasi teknologi. Namun dinilai masih mengalami berbagai kedala dalam sistem kelembagaan dan pemasaran sehingga produknya belum dapat menembus pasar lokal maupun nasional.

Prioritas dalam pembangunan adalah pemberdayaan masyarakat agar mereka mampu menolong dirinya sendiri dan lebih berdaya. Pemberdayaan masyarakat tersebut diupayakan melalui peningkatan kapasitas Sumberdaya Manusia, membangun kelembagaan masyarakat, dan menyediakan fasilitas produksi (teknologi dan modal usaha) agar dapat secara bersaing memasuki pasar tenaga kerja dan kesempatan berusaha yang dapat menciptakan dan meningkatkan pendapatan rumah tangga. Kelembagaan merupakan suatu sistem norma khusus yang menata rangkaian tindakan berpola mantap dan terstruktur dalam meningkatkan kapasitas dan kompetensi petani. Dengan memperhatikan persoalan sistem pengolahan yang dilakukan oleh petani kopi yang semakin kompleks, sebagai dampak dari sistem manajemen pengelolaan yang kurang baik dan kemampuan pemanfaatan teknologi.

Pemberdayaan pada dasarnya merupakan bagian integral dan sekaligus sebagai sarana pelancar atau bahkan penentu kegiatan pembangunan. Menurut Slamet (1989) bahwa pemberdayaan perlu memperhatikan, 1) perubahan adminitrasi pemberdayaan dari yang bersifat regulatif sentralistis menjadi fasilitatif partisipatif dan 2) pentingnya kemauan penyuluh untuk memahami budaya lokal yang seringkali juga mewarnai local agricultural 
practices. Setidaknya ada beberap penyebab masalah sistem pengolahan kopi yang dihadapai petani sehingga usaha tersebut kurang berkembang, yaitu 1) masuknya model-model kelembagaan lain yang banyak berkembang, 2) adanya petani yang terjerat sistem ijon, dan 3) sikap petani yang cenderung apatis sejalan dengan pudarnya nilai-nilai gotong-royong dikalangan masyarakat. Oleh karena itu, perlu dikembangkan dan direvitalisasi melalui proses pemberdayaan masyarakat secara sistematis, terpadu dan berkesinambungan dengan melibatkan seluruh unsur-unsur yang terkait dalamnya.

\section{Tujuan Penelitian}

Tujuan penelitian ini adalah: (1) mendeskripsikan bentuk pemberdayaan masyarakat tani melalui penguatan kelembagaan petani kopi (2) mendeskripsikan model pemberdayaan petani melalui penguatan kelembagaan dan (3) mengetahui kendala-kendala yang dihadapi dalam pemberdayaan petani kopi melalui penguatan kelembagaan.

\section{METODE PENELITIAN}

Penelitian ini dilakukan di Desa Kaongkeongkea Kecamatan Pasarwajo Kabupaten Buton pada bulan Maret - April 2017. Objek penelitian adalah petani yang terlibat dalam pengelolaan kopi sebanyak 45 orang yang tergabung dalam kelompok pengolahan kopi. Sumber data yang digunakan dalam penelitian ini adalah: (1) Informan. Penentuan informan dilakukan dengan menggunakan teknik snow ball sampling, artinya setelah memasuki lokasi penelitian, peneliti menghubungi beberapa informan yang telah ditentukan untuk meminta keterangan, tempat dan peristiwa dari kegiatan kelompok usahatani. Berbagai peristiwa atau kejadian yang berkaitan dengan masalah dan fokus penelitian, antara lain: bentuk pemberdayaan, proses pemberdayaan, kendala yang di hadapi dalam pemberdayaan petani melalui penguatan kelembagaan di Desa Kaongkeongkea Kecamatan Pasarwajo Kabupaten Buton. 3) Dokumen, yaitu dokumen yang digunakan adalah dokumen yang berkaitan dengan substansi penelitian yang diperoleh dari instansi pemerintah, antara lain dinas pertanian dan perkebunan, perindustrian dan perdagangan, badan pelaksana penyuluhan dan kantor kecamatan/desa.

\section{Teknik Pengumpulan Data}

Proses pengumpulan data dilakukan melalui tahap-tahap sebagai berikut:

1) Wawancara mendalam (indepth interview), yang dilakukan untuk memperoleh informasi dan mengungkapkan deskripsi tentang proses pemberdayaan petani kopi dan halhal lain yang berkaitan dengan pemberdayaan petani kopi. 2) Pengamatan (observasi), dilakukan untuk memperoleh dan mengungkapkan gambaran yang utuh dan sistematis tentang suasana yang melingkupi proses pemberdayaan petani kopi dan 3) Dokumentasi, dilakukan untuk mendapatkan data sekunder yang dilakukan dengan cara mengumpulkan data-data dokumentasi tentang proses pemberdayaan petani kopi.

\section{Teknik Analisis Data}

Analisis data menggunakan metode deskriptif, yaitu penelitian yang berusaha mendeskripsikan atau menggambarkan hubungan antara fenomena yang diteliti secara sistematis, faktual dan akurat (Kusmayadi, 2004). Metode ini digunakan untuk mendapatkan data informasi yang mendalam namun menggambarkan kondisi riil yang ada secara menyeluruh dan apa adanya atas fokus masalah yang ditetapkan. Guna mendapatkan data di lapangan meliputi yaitu melalui studi pustaka, wawancara, dan observasi langsung. 
Wawancara secara mendalam (depth interview) akan dilakukan kepada sejumlah narasumber secara mendalam tentang bentuk, proses dan kendala pemberdayaan petani kopi melalui penguatan kelembagaan melalui Focus Group Discussion.

\section{HASIL DAN PEMBAHASAN}

a) Bentuk pemberdayaan petani kopi melalui penguatan kelembagaan

Bentuk pemberdayaan petani kopi melalui penguatan kelembagaan di Desa kaongkeongkea Kecamatan Pasarwajo Kabupaten Buton, dijelaskan pada Tabel 1 sebagai berikut:

Tabel 1. Bentuk pemberdayaan petani kopi melalui penguatan kelembagaan

\begin{tabular}{|c|c|c|}
\hline No & Bentuk pemberdayaan & Dimensi Pemberdayaan \\
\hline 1 & $\begin{array}{l}\text { Peningkatan } \\
\text { kapasitas SDM }\end{array}$ & $\begin{array}{l}\text { 1) Pembelajaran pemahaman dan } \\
\text { keterampilan tentang sistem } \\
\text { pengolahan } \\
\text { 2) Peningkatan partisipasi petani }\end{array}$ \\
\hline 2 & Penguatan modal usahatani & $\begin{array}{lr}\text { 1) Pemberian bantuan sarana } \\
\text { pengolahan } \\
\text { kelompok usaha bersama }\end{array}$ \\
\hline
\end{tabular}

3 Pengembangan kelembagaan Penguatan manajemen pasca panen

Tabel 1 di atas dapat dijelaskan bahwa bentuk pemberdayaan petani Kopi melalui penguatan kelembagaan, yaitu peningkatan kapasistas SDM, penguatan modal usahatani dan pengembangan kelembagaan. Pemberdayaan petani dengan cara: (1) pembelajaran pemahaman dan keterampilan tentang sistem pengolahan kopi melalui penyuluhan, maksud dari kegiatan ini adalah untuk meningkatkan pengetahuan dan keterampilan masyarakat akan pentingnya kelembagaan untuk memperkuat posisi tawar petani sehingga makin berdaya (2) peningkatan partisipasi petani, maksud dari sistem pemberdayaan ini adalah untuk mengetahui potensi masyarakat melakukan kerjasama dalam mengelola kelembagaan petani dalam usahatani kopi.

Pemberdayaan masyarakat dari segi penguatan modal usahatani dilaksanakan melalui usaha: (1) pemberian bantuan sarana produksi, maksud dari program pemberdayaan ini adalah untuk meringankan biaya produksi atau pasca panen, terutama biaya variabel yang setiap musim panen membebani petani, karena naiknya harga kebutuhan, (2) pengembangan kelompok usaha bersama (KUBE) bentuk pemberdayaan ini yaitu untuk membantu petani yang kekurangan modal usahatani dalam suatu kelompok dengan pemberian modal usaha secara bergulir agar petani dapat mengelola usahataninya dengan berkerjasama untuk menambah kekuatan pengembangan kelembagaan sehingga usahatani tersebut dapat berkelanjutan.

Pengembangan sistem pengolahan merupakan bentuk pemberdayaan masyarakat yang dikembangkan untuk menguatkan posisi petani dari segi penguatan manajemen pasca panen. Bentuk pemberdayaan masyarakat ini diarahkan untuk meningkatkan posisi petani dalam mengelola kelembagaan pengolahan kopi dengan menyimpan hasil panennya sebelum dijual sesuai harga pasar.

b) Model pemberdayaan petani kopi Desa Kaongkeongkea melalui penguatan kelembagaan. 
Model pemberdayaan petani kopi Desa Kaongkeongkea melalui penguatan kelembagaan di Desa Kaongkeongkea dijelaskan pada Tabel 2 sebagai berikut

Tabel 2. Model Pemberdayaan Kelembagaan Petani Kopi Desa Kaongkeongkea melalui penguatan kelembagaan.

\begin{tabular}{|c|c|c|}
\hline No & Model pemberdayaan petani kopi & Dimensi pemberdayaan \\
\hline 1 & $\begin{array}{l}\text { Menciptakan situasi atau iklim } \\
\text { Social }\end{array}$ & $\begin{array}{l}\text { Memotivasi masyarakat tani dalam } \\
\text { memperkuat kelembagaan lumbung } \\
\text { pangan desa }\end{array}$ \\
\hline 2 & $\begin{array}{l}\text { Memperkuat potensi atau daya } \\
\text { yang dimiliki masyarakat tani }\end{array}$ & $\begin{array}{l}\text { - Memberikan akses informasi pasar } \\
\text { - Membangun jalan akses usahatani }\end{array}$ \\
\hline 3 & $\begin{array}{l}\text { Melindungi masyarakat tani dari } \\
\text { segala kelemahannya }\end{array}$ & $\begin{array}{l}\text { Menetapkan harga dasar pembelian } \\
\text { gabah dari usaha pemerintah }\end{array}$ \\
\hline
\end{tabular}

Pada Tabel 2 menjelaskan bahwa model pemberdayaan petani melalui penguatan kelembagaan, yaitu: (1) menciptakan situasi atau iklim sosial, (2) memperkuat potensi atau daya yang dimiliki petani dan (3) melindungi petani dari segala kelemahannya.

Model pemberdayaan petani dengan menciptakan situasi atau iklim sosial yang memungkinkan potensi petani berkembang (enabling). Proses ini dilakukan dalam bentuk memotivasi petani agar dapat memperkuat kelembagaan dalam pengolahan kopi sesuai dengan kemampuannya. Hasil penelitian ini sesuai dengan pendapat Maslow (1956) yang menyatakan bahwa, setiap individu termotivasi dengan cara kebutuhan yang menjadi bawaan sejak lahir dan membuat individu tersebut terpuaskan dengan kebutuhannya, sehingga dapat bertahan hidup. Selanjutnya McClelland (1961) menjelaskan bahwa individu akan mengembangkan potensinya melalui motivasinya untuk berprestasi (achievement motivation) yang berhubungan dengan tiga kebutuhan, yaitu: (1) kebutuhan akan prestasi (need of achievement) $n$-Ach), 2) kebutuhan akan kekuasaan (need of power) $n$ Power dan 3) kebutuhan berafiliasi (need of affiliation) $n$-Aff.

Memperkuat potensi atau daya yang dimiliki petani merupakan proses pemberdayaan yang berhubungan dengan menyediaan input untuk memperkuat posisi petani dalam mengembangkan kelembagaan dalam pengolahan kopi. Proses pemberdayaan ini dilakukan melalui penguatan pemberian akses informasi pasar agar petani dapat mengetahui perkembangan harga kopi pada setiap musim panen, sehingga mereka tidak terjerat oleh sistem ijon yang senantiasa berkembang di pedesaan. Selain itu penguatan potensi masyarakat melalui proses pemberdayaan ini yaitu dengan membangun tempat pengolahan kopi yang baik, yaitu sesuai dengan standar industri pengolahan dan sistem manajemen usahatani sehingga petani tidak mengalami kendala dalam mencapai kompleks usahatani dan proses pemasaran hasil produksi. Hal ini sesuai dengan pendapat Hendriyati, dkk (2005) yang menjelaskan bahwa pembangunan prasarana dan sarana dasar seperti jalan, irigasi, listrik, sekolah, dan lain-lain merupakan aspek yang penting dalam memperkuat potensi masyarakat sebagai usaha membuka keterisoliran dan keterbelakangan penduduk suatu wilayah.

Proses pemberdayaan petani melalui penguatan kelembagaan dapat dilakukan dengan melindungi petani dari segala kelemahannya. Proses pemberdayaan masyarakat ini menitik beratkan pada penguatan penetapan harga dasar pembelian kopi dari pemerintah. Penetapan harga dasar ini sangat diperlukan untuk melindungi hasil produksi petani dari fluktuatifnya harga kopi dipasaran. Usaha ini perlu dilakukan oleh pemerintah dengan memberikan perlindungan kepada petani melalui aturan daerah atau surat keputusan 
gubernur/bupati/walikota tentang penetapan harga dasar pembelian kopi dan juga hasil bumi lainnya di pedesaan sebagai usaha penguatan kelembagaan dalam mendukung program pemberdayaan petani.

c) Kendala-kendala yang dihadapi dalam pemberdayaan petani melalui penguatan kelembagaan

Kendala-kendala yang dihadapi dalam pemberdayaan petani melalui penguatan kelembagaan di Desa Kaongkeongkea disajikan pada Tabel 3 sebagai berikut:

Tabel 3. Kendala internal dan eksternal dalam pemberdayaan petani melalui penguatan kelembagaan

\begin{tabular}{lll}
\hline No & Kendala pemberdayaan petani & Potensi kendala pemberdayaan \\
\hline 1 & Kendala internal & -Terbatasnya sumberdaya \\
& & manusia \\
& & -Terhatasnva anooaran nenoembanoan \\
\hline 2 & Kendala eksternal & $\begin{array}{l}\text { Belum terjalinnya kemitraan } \\
\text { petani dengan pihak terkait }\end{array}$ \\
\hline
\end{tabular}

Berdasarkan Tabel 3 di atas, maka kendala-kendala yang dihadapi dalam pemberdayaan petani melalui penguatan kelembagaan yaitu berupa kendala internal dan eksternal. Kendala internal berupa terbatasanya sumberdaya manusia khususnya petani, dan terbatasnya anggaran untuk pengembangan usahatani. Adanya kendala internal ini dapat menyebabkan manajemen pengelolaan dan motivasi petani dalam memperkuat kelembagaan petani menjadi berkurang, karena pengelolaan kelembagaan memerlukan sumberdaya manusia yang memiliki kompetensi manajemen usahatani yang baik.

Hal ini sesuai dengan pendapat Hendriyanti (2005) yang menjelaskan bahwa potensi Sumber Daya Manusia dan penyediaan anggaran berpengaruh pada proses revitalisasi kelembagaan petani. Untuk mencegah kendala tersebut, maka diperlukan program pelatihan manajemen organisasi bagi petani dan penyediaan anggaran pada setiap tahunnya melalui dinas instansi terkait. Kendala eksternal dalam proses pemberdayaan masyarakat tani melalui penguatan kelembagaan yaitu belum terjalinnya kemitraan yang baik antara petani dengan stakeholder sehingga perlu membangun pola kemitraan yang bersifat simbiosis mutualisme yang berdampak baik bagi pengembangan program pemberdayaan dan penguatan kelembagaan petani. Hal ini juga sejalan dengan kesimpulan Edy,S (2016) bahwa persepsi petani terhadap agroindustri kopi yang baik atau posif akan berdampak terhadap perilaku petani dalam sistem pengohan kopi yang makin baik sehingga dapat meningkatkan pendapatan dan kesejahteraan petani.

\section{KESIMPULAN DAN SARAN}

Berdasarkan hasil dan pembahasan, maka pada penelitian ini dapat disimpulkan hal-hal sebagai berikut: 1) Bentuk pemberdayaan masyarakat tani melalui penguatan kelembagaan petani yaitu: peningkatan kapasitas Sumber Daya Manusia dan penguatan modal usahatani, 2) Model pemberdayaan masyarakat tani melalui penguatan kelembagaan petani, yaitu: menciptakan situasi atau iklim sosial, memperkuat potensi atau daya yang dimiliki petani dan melindungi dari segala kelemahannya, (c) Kendala-kendala yang dihadapi dalam pemberdayaan petani melalui penguatan kelembagaan antara lain: kendala internal yaitu: terbatasnya sumberdaya manusia khususnya petani dan terbatasnya 
anggaran di tingkat petani dalam mengembangkan usahatani. Dan kendala eksternal yaitu belum terjalinnya kemitraan yang baik antara petani.

Sebagai saran dalam penelitian ini adalah penguatan kelembagaan masih sangat terbatas dan belum mampu untuk mengantisipasi terjadinya serangan hama dan usia tanaman yang sudah tua. Oleh karena itu, kegiatan penyuluhan tentang pegelolaan secara menyeluruh. Mulai dari penanaman, pemeliharan, panen dan pasca panen sehingga potensi kopi di desa ini dapat dikembangkan dan direvitalisasi melalui proses pemberdayaan masyarakat tani secara sistematis, terpadu dan berkesinambungan dengan keterlibatan seluruh stakeholder.

\section{DAFTAR PUSTAKA}

Edy, S, 2016. Persepsi Petani Terhadap Agroindustri Kopi Dalam Meningkatan Kualitas Hidup di Kecamatan Pasarwajo Kabupaten Buton. Media Agribisnis Volume 1 Edisi 12016.

Hendriyati, Suradi, Sugiyanto. 2005. Pengembangan Model Pemberdayaan Komunitas Adat Terpencil. Pusat Penelitian dan Pengembangan Usaha Kesejahteraan Sosial. Badan Pelatihan dan Pengembangan Sosial. Departemen Sosial RI. Jakarta.

Maslow A. 1956. Maslow's Hierarchy of Needs motivational model. http://businessballs.com/maslow.htm [12 April 2017].

McClelland CD. 1961. David C Mcclelland's Motivational Needs Theory. http://businessballs.com/davidmcclelland.htm [12 April 2017].

Kusmayadi .2004. Statistika Deskriptif. Jakarta: PT. Gramedia Pustaka Utama.

Pasaribu, Sabat M, 2011. Pengembangan Agroindustri Perdesaan Dengan Pendekatan One Vilage One Product (OVOP). Jurnal Forum Agro Ekonomi (FAE) Volume 29 No. 1 Tahun 2011.

Makmur, Syarif, 2008. Pemberdayaan Sumber Daya Manusia dan Efektifitas Organisasi. PT. Rajagrafindo Persada. Jakarta 